\title{
THE INFLUNCE OF KWL STRATEGY USE IN TEACHING READING FOR EFL LEARNERS IN CLASS ROOM
}

\author{
Endang Haryanto \\ State Islamic Institute of Bengkulu
}

\begin{abstract}
Reading is a process to to get both the information and knowledge from written sources or text. To make it easiers there are some applicable strategies. Based on some related literatures, KWL can be implemented in teaching reading for EFL learners in class room with varied reading skill levels. Hence this strategy is assumed is appropriate use in Indonesian school context. This reasearch is intended to investigate how effective the strategy in helping leraners to enhanch their ability in reading. The samples of this study were the second year students of SMAN 07 South Bemgkulu in 2019. The research design use is experimental study with expemental and control class. From the result of the study the data showed that the students taught with KWL achieved better reading comprehension than those were not taught with the strategy.
\end{abstract}

Keywords: reading comprehension, KWL, EFL

\section{Introduction}

Language has an important role in developing learners' intellectual, social, and emotional value and it supports the success in learning all subject matters. Hopefully, studying language will help the learner to recognize themselves, their cultures and other cultures. Besides, learning language can help learners to express their ideas and feeling. It also can help them to participate in society.

English is one of important languages in this world. People use English to communicate with others in this world, express their idea and their mind. Basically, learning English is very important for junior and senior high school students, especially in Indonesia. There are four skills in English that have to be improved by students, they are listening, speaking, reading and writing.

Nowadays, the use of English in Indonesia is not only found in the formal education but also in their environments, such as television, electronic media, and printed media. English words can be seen. The preceding facts prove that there are many English words everywhere. Every product, advertising, and food package uses English as their way to introduce their product. Ironically although it has been taught in Indonesia for many years, few students have had good skill of English. English is still regarded as a difficult subject. They do not have a bravery to use English. The bravery to use English is not the only factor that makes English difficult, the other factors is teacher, material, situation on the class, and the environment of the students.

In English, reading is not only to read the text but also to understand content of the text. Vocabulary and grammar are also important in English. However, the main goal of reading is to understand the ideas of the text. Reading will mean dealing with language messages in written or printed form. Based on 
Finochiarro (1973:119), reading is defined as a process of bringing meaning to and getting meaning from printed or written material. Thus Nuttal (as cited in Urquhart 1998:17), having considered definitions of reading in terms of reading aloud, or decoding, settles for the extraction of meaning from written messages.

Based on the explanation above, it can be concluded that reading is one of English language skills considered important in our life. We will get some information through reading. The students should read many kinds of printed media if they want to get information and that is why students are taught reading skill in English. English teacher should create a better technique in teaching reading.

Teacher should always try to improve the way of teaching. The government also improves the way of teaching and learning. It is proved by the changing of curriculum, which is used. The changing of curriculum is aimed at developing the English teaching to the learners. In curriculum, the aim of English teaching is to understand and produce spoken and written text. The learners are hoped, after graduating from school, to be able to communicate in daily life or in their work orally and reading or written in English.

Reading is a selective process. It involves partial use of available minimal language cues selected from perceptual input on the basis of the reader's expectation. As this partial information is processed, tentative decisions are made to be confirmed, rejected or refined as reading progresses (Goodman, 1971:260).

Toprak (2009) stated that Three Phase Technique in reading are namely, pre-reading, while reading and post reading. In pre reading (warm-up, into, before reading) activities introduce students to a particular text, elicit or provide appropriate background knowledge. Then, in while reading (during, through reading) exercises help students develop reading strategies, improve their control of the foreign language, and decode problematic text passages. And then, in post reading (after, follow-up, beyond reading) exercises first check students' comprehension and then lead students to a deeper analysis of the text.

Good teachers are always searching for ways to enhance learning in their classrooms. Researchers and practitioners alike continue to develop and refine strategies which improve comprehension and increase retention while nourishing students' ability to learn independently. The K-W-L strategy (What-we know; what we want to know; what we learned), first described by Ogle (1986), is such a strategy. Current research on learning indicates that good learners make connections between prior knowledge and new knowledge and in the process, construct their own meanings (Anderson, 1984).

Based on some researches/studies, KWL is one of reading techniques that can improve students' reading comprehension. The data indicate that the technique is an effective tool to help students to be more active thinkers and it is also useful to help teachers to be more active in teaching reading. Ogle (1986) stated that develop the strategy for activating students' prior knowledge of a subject or topic and encourage in active reading. Students begin by brainstorming everything they know about the topic.

This information is recorded in the $\mathrm{K}$ column of a KWL chart. Then, students make a list of questions about what they want to know about the topic. 
These questions are listed in the $\mathrm{W}$ column of the chart. During or after reading, students answer the questions that are in the $\mathrm{W}$ column. This new information that they learned is recorded in the L column of the KWL chart (Fengjuan, 2010).

Further, According to Cantrell et al. (2000) the KWL groups have more statistically significant degree in content material than did the Summary groups. In addition, according to Al- Khateeb and Mohammad (2010) that KWL strategy does contribute in improving the reader's comprehension level and in achieving meaningful learning through activating previous knowledge related to the reading text.

\section{Literature Review}

\subsection{Definition of Reading}

According to Tickou (as cited in Yusuf, 2012:17), "Reading is a process of looking at and understanding written language. English texts enrich the readers' new vocabulary, structures of English, sentences and new knowledge." We can enrich our vocabulary and also get more new knowledge from reading. It means that if we are not reading, we will not get new information. In addition, we will be stuck in our mindset and will not improve our knowledge. Then, by reading we get new vocabulary, sentences and knowledge.

Moreover, based on Finochiarro (1973:119), reading is defined as a process of bringing meaning to and getting meaning from printed or written material. Thus Nuttal (as cited in in Urquhart1998:17), having considered definitions of reading in terms of reading aloud, or decoding, settles for the extraction of meaning from written messages.

Reading is not only a receptive skill, but also an active one in that it primarily includes the cognitive abilities such as predicting and/or guessing. In the prediction process learners are asked to talk about the title of the text or comment on some illustrations (pictures) if provided any to set the scene. Therefore, language teachers should improve their students' ability to infer through the use of systematic practice and questioning techniques. Doing so will encourage students to anticipate the content of a text from its title and illustrations or the end of a story from the preceding paragraphs (Grellet, 1987:107).

This theory places heavy emphasis on the importance of the learners' background knowledge. In a sense, reading can be regarded as a psycholinguistic guessing game in which the reader reconstructs, as well as he can, a message which has been encoded by a writer as a graphic display (Goodman, 1971:89).

Another definition of reading is stated by Stanferr, he states that reading is a mental process requiring accurate word recognizition, ability to call to mind particular meanings, and ability to shift or reassociate meanings (Petty and Jensen, 1987:208).

According to Kenneth Goodman (1971:65) that reading is a receptive language process. It is a psycholinguistic process in that it starts with a linguistic surface representation encoded by a writer and ends with meaning which the reader construct. 
Comprehension is the goal of reading. Bartram and Parry in Regina stated that many students who read in a foreign language think, "reading means understanding and/or translating every word". Good readers do not always try to understand every word, and especially the first time they read for comprehension. The primary purpose for reading is sometimes overlooked when students are asked to read difficult text; raising student's awareness of main ideas in a text and exploring the organization of a text are essential for good comprehension Richards (as cited in Eryawati, 2010:15). In conclusion, reading is the process of bring and get information either reading aloud or decoding the extraction of meaning form written message. Reading are also involved the readers in interpreting what the writers means. However, the function of reading is to enrich our vocabulary and our information.

\subsection{Reading Comprehension}

Reading comprehension is the process of understanding and constructing meaning from a piece of text. According to Olson and Diller (1982:42), what is meant by reading comprehension is a term used to identify those skills needed to understand and apply information contained in a written material. Other than that, Harris and Sipay (1980:179) say that reading comprehension ability is learned to be a set of generalized knowledge acquisition skills which permits people to acquire and exhibit information gained as a consequence of reading printed language. Reading comprehension is the ability to gain information from the texts for the purpose to know the whole information deeply. So that it will force the readers to read the whole texts to gain the covert information.

However, Comprehension is a highly complex cognitive process involving the intentional interaction between the reader and the text to create meaning. In other words, comprehension doesn't just happen; it requires effort. Readers must intentionally and purposefully work to create meaning from what they read (David Chard, 2008).

Reading comprehension is crucial for every profession and lifestyle. According to Al- Khateeb and Mohammad (2010:472), reading comprehension is a dynamic interactive process between the reader and the reading material. Reading comprehension is also defined as the level of understanding of a text. This understanding comes from the interaction between the words that are written and how they encourage knowledge outside the text. They concluded that (1) vocabulary knowledge, (2) reading comprehension instruction based upon reading fictional books instead of literary books, and (3) practices were critical to effective reading comprehension teaching.

There are some levels of Reading Comprehension as follows: 
Reading comprehension can be classified into different levels. Teachers need to be aware that there are actually three main levels of comprehension; literal comprehension, interpretative comprehension, and critical comprehension.

According to Burns, Roe, \& Ross (1984) stated that there are some level to understand the material that they read and every level have different levels. There are three levels of reading comprehension. Those are literal comprehension, interpretative comprehension, critical reading.

\section{A. Literal Comprehension}

Burns, Roe, \& Ross (1984:177) stated that literal comprehension involves acquiring information that is directly stated in a selection, is important in and of it and is also prerequisite for higher-level understanding. Purpose of reading may range from simple to complex, encouraging reorganization and recall or detailed facts. Abilities includes this comprehension level are knowledge of word meaning, recall of detail directly stated or paraphrased in own word, understanding of grammatical clue-subject, verb pronoun, conjunction, and so forth, recall main idea explicitly stated, and the last is knowledge of sequence of information presented in the passage. At this level, teachers can ask students to find information and ideas that are explicitly stated in the text.

\section{B. Interpretative Comprehension}

According to Burns, Roe, \& Ross (1984:183) interpretative comprehension is the process deriving ideas that are implied rather than directly stated. Skills for interpretive reading include: (1) inferring main ideas of passages in which the main ideas are not directly stated, (2) Inferring cause-effect relationships when they are not directly stated. (3) Inferring referents of pronouns, (4) Inferring referents of adverbs, (5) inferring omitted word, (6) detecting mood,

(7) detecting author's purpose in writing.

C. Critical Comprehension

According to Burns, Roe, \& Ross (1984: 190) Critical comprehension is evaluating written material comparing the ideas discovered in the material with known standards and drawing conclusions about their accuracy, appropriateness, and timeliness. Abilities here include personally reacting to the information in a passage indicating its meaning to the reader whereas analyzing and evaluating the quality of written information in terms of standards.

\subsection{Teaching Reading}

Reading means reading and understanding. A foreign language learners who says," I can read the words but I don't know what they mean' is not, therefore, reading in this sense. He or she is merely decoding - translating written symbols into corresponding sounds.

Types of Reading Activities: 
1. Text followed by comprehension question activities

Conventional types of reading activity or text consists of a text followed by comprehension questions. In this time, we shall look at some examples of this kind of material, consider what makes it more or less effective, and suggests variations. Guessing the answers for comprehension before reading is only one way of motivating learners to read a text. There are, of course, many others and these can often be based on the learners' own previous ideas on the topic.

Sometimes no actual task is necessary, if the passage is easy and motivating to read, the learner reads, as in his or her own mother tongue, for enjoyment or information, but task is useful for two reasons: first, it may provide the learners with a purpose in reading and make the whole activity more interesting and effective: second, we need to know how well our learners reading, and we can get this information conveniently through looking at the results of comprehension tasks. An example of a task, which is not based on comprehension question, might be giving the learners a set of titles together with a set of extract from different newspaper articles or stories and asking them to match the titles to the appropriate extracts.

\section{Improving Reading Skills}

Getting the learners to understand a simple text, is only the beginning. Reading skills need to be fostered so that learners can cope with more and more sophisticated texts and tasks, and deal with them efficiently, quickly, appropriately, and skillfully.

The characteristics of efficient reading and implications for teaching are as follows:

a. The text should be accessible if learners cannot understand vital informati6on without looking up words or being given extra information from elsewhere then the activity may improve their vocabulary and general knowledge, but will be less useful as an aid to improving their reading skills as such. Note that the appropriateness of language level depends to some extent on the task. A quite difficult text may provide useful reading for an intermediate class if the task demands understanding only of those parts that are readily comprehensible to them.

b. There are some controversies over whether learners can improve reading speed as such through training and in any case, different reading purposes demand different speeds. The most useful thing teachers can do is to provide our students with the opportunities to do as much successful reading as possible, including a varied diet of types of reading (fast, slow, skimming, scanning, and studying). The aim is to encourage recognition of common words or word combinations. 
c. Scanning tasks (where the student is asked in advance to look out for a specific item of information while reading) are very useful for getting learners to read selectively. Careful selection of texts is also important.

d. Again, task aimed at encouraging learners to guess or "do without" words can help to habituate them to use these strategies. The dictionary is often over-used, resulting in slower, less fluent reading, as well as frequent misunderstanding through the selection of the wrong definition. Learners should, of course, know how to use the dictionary, but they should also learn when it is necessary and when an intelligent guess is preferable. Overall, the dictionary is best used as a means to confirm or disprove a preliminary guess of their own, based on understanding of the context.

e. There are tasks, which specifically encourage prediction, such as "What do you think will happen next" or "What you think the next few words will be?"

f. Tasks should encourage learners to apply their own background knowledge and experience to the reading of texts.

g. Overall, it is best to give the task in advance; so that learners know, what their purpose is in reading. The exception is the case of instructional pause (novels or stories) when the reading material is motivating in itself and a task may actually distract and spoil the readers enjoyment.

h. We should make sure that our learners are provided with a variety of different kinds of reading tasks, and encourage them explicitly to use different strategies.

\subsection{KWL Technique}

The letters in the name, KWL, stand for the process of making meaning that begins with what students KNOW, moves to the articulation of questions of what they WANT TO KNOW, and continues as students record what they LEARN. The strategy is designed to be used by a teacher and group of students working together. It is then easily transferred into a method for students' independent study. In using the strategy the teacher first leads the group through an oral discussion of each of the components and then turns the process over to students to individually write their own ideas and questions on a personal worksheet.

Research has made quite clear the importance of the active, constructive nature of reading and learning; good learners link their prior knowledge to new 
information, reorganize it and create their own meanings (Anderson, 1984). The KWL strategy, described in this paper, is designed to help readers do just that. KWL provides a framework for learning that can be used across content areas to help students become active constructors of meaning.

Based on Region XIV Comprehension Center Educational Testing Service (1995), KWL is a strategy that models is the active thinking needed when reading expository text. The Letters $\mathrm{K}, \mathrm{W}, \mathrm{L}$ stand for three activities students engage in when reading to learn: recalling what they Know, determining what they Want to learn, and identifying what they Learn as they read.

This strategy is designed to help students develop a more active approach to reading expository material. Teachers as model and stimulate the kinds of thinking needed for learning and then give students individual opportunities to list what they know, what questions they want to answer, and what they have learned from reading the text. In this way, the benefits of group instruction are combined with individual student commitment and responsibility. The strategy was developed to translate current research findings about the active, constructive nature of reading into an instructional lesson format. According to Ogle (1986) as cited in Region XIV Comprehensive Center Educational Testing Service (1995), in classroom testing, students became more effective thinker and remember better what they read through KWL. Furthermore, it is also helping teachers better communicate active nature of reading.

1. Group instruction.

a First, the teacher engages students in a discussion of what they as a group already know about the concept the teacher or the students have selected to introduce the lesson. The teacher lists this information on the whiteboard. When disagreements and questions emerge, the teacher notes them and suggests that students may want to include them on the center column as questions they want to have answered.

b Second, after students have volunteered all that they can think of about the concept, they should be asked to categorize the information they have generated. The teacher may need to identify one general category that incorporates two or more pieces of information on the board to model the building of chunks or categories.

c Third, after the students are somewhat familiar with this process, they should be asked to anticipate the categories of information they would expect to have included in an article on the topic. The categories of information identified will be useful in processing the information they read and in future reading of a similar nature. 
2. Individual reflection.

After the group introduction to the topic, students should be asked individually to list what they feel confident they KNOW about the concept. They can also write down the categories they think are most likely to be included. At this time, the teacher should help students raise those questions that have emerged during the discussion or that come from thinking of the major categories of information they expect to find.

3. Reading.

Students should be directed to read the text once they have focused both on what they know and what they want to find out from reading. Depending on the length and difficulty of the text and the class composition, the text can either be read as a unit or be broken into sections for reading and discussion. As they read, students should write down information they learn as well as new questions that emerge.

\section{Assessment of learning.}

The final step in the process is to engage the students in a discussion of what they have learned from reading. Their questions should be reviewed to determine how they were resolved. If some have not been answered satisfactorily, students should be encouraged to continue their search for information.

In KWL, Students' prior knowledge is activated by asking them what they already know. Prior knowledge should be discussed before reading the text to help set the stage for what is coming. During reading, students should be encouraged to make connections to the text from their experience and the teacher should model this process using his or her own connections. After reading, the discussion should center on how the connections helped students to better understand the text and how the text helped them to build their foundation of prior knowledge. Having more prior knowledge generally aids comprehension.

There are many aspects to prior knowledge, including knowledge of the world, cultural knowledge, subject-matter knowledge and linguistic knowledge. A reader's interest in a subject matter will also influence the level of prior knowledge. All of these factors are important to different degrees, depending on the reading task. A reader's knowledge of the world depends on lived experience. This is different in different countries, regions and cultures.

According to Al- Khateeb and Mohammad (2010:476), KWL strategy is a set of well organized steps to be followed by a student to reach reading comprehension. It is composed of three columned maps to be drawn on the board. This strategy consists mainly of three precise questions, asked by and directed to the students themselves.

1) What do I know about the topic? 
The student asks himself this question before he reads the text and tries to write all what he knows about the topic of the text to be read. This question aims at brainstorming the reader to recall as much previous knowledge and information related to the topic as possible.

2) What do I want to know?

The student writes whatever he likes to know about the topic, subject of the reading text. He makes questions. Thus, while he is reading the text, he attempts to find answers to them.

3) What did I learn?

The reader answers this question after he has read the text.

Sulistyo (2011:88) said that:

The KWL technique is essentially like the before and after matrix in that it considers the knowledge the students already know about the topic before reading the text and the knowledge the students know about the topic after reading the text. However, the K-W-L (know, want to know and learn) technique incorporates another aspect, namely the knowledge the sttudents want to know about the topic before reading the text.

According Corner (2006), KWL strategy have several purposes: (a) get student's prior knowledge, (b) sets a purpose for reading, (c) helps students to monitor their comprehension, (d) allows students to assess their comprehension of the text, and (e) provides an opportunity for students to expand ideas the text.

Often students are confronted with a great deal of information they are expected to internalize in short periods of time. When it is important to retain the information the two post-reading components of the strategy, mapping and summarizing, are valuable. These were added after the original KWL was developed because teachers found that students still needed help rehearsing new information in ways that would make it memorable (Carr \& Ogle, 1987). Once students have completed their reading and note-making, they go back and create a graphic map or diagram of the ideas. This map should include both what the student knew prior to reading and the important information that has been gained. Some teachers suggest students use two colors of pen or pencil to make even clearer the weaving together of new and old information. As students create a map of their ideas they should be using some of the basic structures or frames inherent to the content presentation. When the map is completed it is easy for students to write summaries; they simply use the category labels on their maps as main ideas and the subsumed information as details or illustrations. Research (Carr \& Ogle, 1987) has demonstrated the value of the post-reading mapping and summarizing for long-term content retention. 


\section{Method}

\subsection{Research Design}

The research design of this study is experimental. It is a quantitative study which focuses on the effectiveness of using KWL technique in teaching reading comprehension. Type of the experimental design used in this study is quasiexperimental. The researcher can only assign randomly to select as experimental class and control different treatment to two different classes

\subsection{Population and Sample}

In SMAN 7Bengkulu Selatan there are 4 classes of second year students. From those classes, the writer chose two classes of the second grade as experimental class and control class. The population of students of second grade is 108 students.

Randomly select one of the classes into experimental group and the other one into control group (Latief, 2013:96). The sample that selected was taken two classes from XI A as a control class and XI B as an experimental class. Before the research, both control and experimental class are tested to make sure that they have the same level of background knowledge.

The writer assigns into two groups $\mathrm{E}$ and $\mathrm{C}$. Each of these groups represents the score of the class. Group E as the score of experiment class (XI-A) and $\mathrm{C}$ as the score of control class (XI-B). The experimental class is taught using KWL technique and the control class is taught using instructional pause technique.

\subsection{Research Instrument}

The research instument is used to collect data. The test is used for pre-test and post-test. The reading test is used to know the students' ability in reading comprehension. The reading test is in the form of multiple choice with four options. The reading tests is used as pre-test and post-test.

\section{Findings}

\subsubsection{Descriptive Analysis of Pre-test and Post-test}

The researcher analyzes the data after collecting the data both pre-test score and post-test score. The researcher analyzes the data by using SPSS program. The result of data analysis is as follow:

Table 4.1 Descriptive statistics of pre-test and post-test at Experimental Class

\begin{tabular}{lcccccccc}
\hline & N & Range & Minimum & Maximum & Sum & Mean & $\begin{array}{c}\text { Std. } \\
\text { Deviation }\end{array}$ & Variance \\
\hline Pre-Test & 26 & 52.00 & 32.00 & 84.00 & $\begin{array}{c}1760.0 \\
0\end{array}$ & 67.6923 & 15.67359 & 245.662 \\
Post-Test & 26 & 48.00 & 44.00 & 92.00 & $\begin{array}{c}1860.0 \\
0\end{array}$ & 71.5385 & 16.56317 & 274.338 \\
$\begin{array}{l}\text { Valid N } \\
\text { (listwise) }\end{array}$ & 26 & & & & & & & \\
\hline
\end{tabular}




\begin{tabular}{lcccccccc}
\hline & $\mathrm{N}$ & Range & Minimum & Maximum & Sum & Mean & $\begin{array}{c}\text { Std. } \\
\text { Deviation }\end{array}$ & Variance \\
\hline Pre-Test & 26 & 52.00 & 32.00 & 84.00 & $\begin{array}{c}1760.0 \\
0\end{array}$ & 67.6923 & 15.67359 & 245.662 \\
Post-Test & 26 & 48.00 & 44.00 & 92.00 & $\begin{array}{c}1860.0 \\
0\end{array}$ & 71.5385 & 16.56317 & 274.338 \\
\hline
\end{tabular}

Table 4.2 Descriptive statistics of pre-test and post-test at Control Class

\begin{tabular}{lcccccccc}
\hline & N & Range & Minimum & Maximum & Sum & Mean & Std. Deviation Variance \\
\hline Pre-Test & 26 & 56.00 & 32.00 & 88.00 & 1752.00 & 67.3846 & 16.69270 & 278.646 \\
Post-Test & 26 & 56.00 & 32.00 & 88.00 & 1756.00 & 67.5385 & 16.44684 & 270.498 \\
$\begin{array}{l}\text { Valid N } \\
\text { (listwise) }\end{array}$ & 26 & & & & & & & \\
\end{tabular}

The description of students' scores in each category is as follows:

1. The data of experimental group at pre-test showed that the range of the score is 52 , the means is 67.69 , the median is 72 and the mode is 84 .

2. The data of experimental group at post-test showed that the range of the score is 48 , the means is 71.53 , the median is 78 and the mode is 84 .

3. The data of control group at pre-test showed that the range of the score is 56 the means is 67.38 , the median is 70 and the mode is 68 .

4. The data of control group at post-test showed that the range of the score is 56 the means is 67.53, the median 72 is and the mode is 72 .

The descriptions above show that the mean score of the experimental group at pre-test was 67.69 and post-test was 71.53 while the mean score of the control group at pre-test 67.38 and post-test was 67.53 , clearly the obtained data that mean score of the experimental group was higher than the mean score of control group.

\subsubsection{Analysis of Covariance}

The discussion of this study result was analyzed by using analysis of Covariance (ANCOVA) test. It was to know the significant difference between reading comprehension of experimental group and control group.

This computation is to analyze the result of study statistically, namely the alternative hypothesis which stated that students who are taught by KWL technique have better reading comprehension than those whose are taught by instructional pause technique. The null hypothesis was formulated as the studens 
who are taught by KWL do not achieve better reading comprehension than those who are taught by instructional pause technique.

To determine whether the score obtained by the students in both experimental and control group differ significantly after the treatment, the ANCOVA test with the critical value of $p=0.05$ was applied. The following section present the result of the ANCOVA test computation for the reading score.

From the data about the students' achievement in reading comprehension could be obtained. By using program of SPSS version 16, Tests of BetweenSubjects Effects can be seen in the following table.

Table 4.3 Tests of Between-Subjects Effects.

Dependent Variable:Post-Test

\begin{tabular}{lllllll}
\hline Source & $\begin{array}{l}\text { Type III Sum } \\
\text { Squares }\end{array}$ & of & Mean Square & F & Sig. \\
\hline Model & $264641.531^{\mathrm{a}}$ & 3 & 88213.844 & $6.770 \mathrm{E} 3$ & .000 \\
Pre_Test & 12982.454 & 1 & 12982.454 & 996.353 & .000 \\
Class & 191.109 & 2 & 95.555 & 7.333 & .002 \\
Error & 638.469 & 49 & 13.030 & & \\
Total & 265280.000 & 52 & & & \\
\hline
\end{tabular}

a. R Squared $=.998($ Adjusted R Squared $=.997)$

\subsection{Hypothesis Testing}

The ANCOVA test was used to investigate the difference between the means score. The statistically analysis was used to test the statistical hypothesis. The null hypothesis of this research is that the students taught by KWL Technique do not influence significantly their reading comprehension achievement than those taught by instructional pause technique.

The analysis of the significance of the different effect of KWL technique and instructional pause technique resulted in an $\mathrm{F}$ value $7.333(\mathrm{p}<.002)$ the finding showed that the null hypothesis $\left(\mathrm{H}_{0}\right)$ is rejected and alternative hypothesis $\left(\mathrm{H}_{1}\right)$ is accepted. This indicated that the difference of the two means score was significant. Researcher concludes that the implementation of this study of two groups was different significantly and statistically.

\section{Conclusion And Suggestion}

This chapter presents about the conclusion of the research findings in relation to its discussion, and suggestion for English teachers or lecturers, school and future researcher related to the findings of the research. 


\subsection{Conclusion}

As mentioned in the previous chapter, the researcher was to investigate the students taught by KWL Technique have better reading achievement than those taught by instructional pause technique was. After analyzing the data, the researcher found that the average score of post-test in both group was different significantly. The mean score of post-test was 71.53 at experimental group and the mean score of post-test was 67.53 at control group. The students who are thaught by using KWL technique showed their reading comprehension better than students by using instructional pause technique.

Based on the findings had been stated above, the researcher concluded that there was a significant difference of mean score of post-test between experimental group and control group. It means that the alternative hypothesis was accepted, and the null hypothesis was rejected. From the explanation above, it can be concluded that taught using KWL technique was effective to improve the student's reading comprehension. KWL technique is more effective than Instructional pause technique in teaching reading comprehension.

\subsection{Suggestion}

Based on the research findings, discussion and the conclusion of research results, the researcher concluded that between students who have been taught with KWL technique has different comprehension with the students who have been taught with instructional pause technique.

Based on the findings above, some suggestions are primarily purposed to the teacher, school, and future researcher.

\section{For Teachers}

The English teacher should employ various technique and method in teaching language especially reading. It will make learning become fun. The English teacher should choose the appropriate materials and the appropriate technique related to the topic to improve students' interest and effectiveness in the learning process. The teacher should be a facilitator and motivator in the teaching and learning process. The teacher becomes facilitator in learning process or discussion and becomes motivator to make students get active participation.

\section{For School}

Based on the conclusions above, the writer would like to suggest that school of senior high school especially at MA Usymuni Terate Sumenep would like to implement KWL technique in teaching reading comprehension for English lesson to improve students' acheivement.

3. For Future Researchers

Future researchers should take longer time to conduct such study in order to modify the treatment and apply the technique that is used to increase students' reading comprehension. They should add the instrument so that the result can be 
more effective. They should also do the research more intensive so that the result can be more effective and significant. 


\section{References}

Achmad, P. 2009. The Effectiveness of KWL (Know, Want To Learn, Learned) in Teaching of Reading Viewed From Students' English Learning Interest in the Ninth Grade Students of SMP Negeri 8 Probolinggo Academic Year 2009-2010. Unpublished Thesis. Solo: University of Solo.

Al- Khateeb, O. S. M., \& Mohammad. 2010. The Impact of Using KWL Strategy on Grade Ten Female Students' Reading Comprehension of Religious Concepts in Ma'an City. European Journal of Social Sciences - Volume 12, Number 3. (online), (http://www.eurojournals.com/ejss_12_3_14.pdf, Accessed on April, 01, 2015)

Anderson, R.C. 1984. Role of the reader's schema in comprehension, learning and memory. In R.C. Anderson, J. Osborn, \&R.J. Tierney (Eds.), Learning to read in America's schools: Basal readers and content area texts (pp. 243258). Hillsdale NJ: Erlbaum.

Ary, D., Jacobs, L.C. \& Sorensen, C. 2010. Introduction to Research in Education $\left(8^{\text {nd }}\right.$ ed). New York: Printed in the United States of America

Brown, D. 2000. Principles of Language Learning and Teaching, Fourth Edition. New York: Addison Wesley Longman, Inc

Burns, C. P., Roe, D. B. \& Ross, P. E. 1984. Teaching Reading in Today's Elementary Schools. U.S.A: Houghton Mifflin Company.

Cantrell, R. J., Joseps, A. F. \& Edward, A. D. 2000. Exploring the Effectiveness of Journal Writing on Learning Social Studies: A Comparative Study. Reading Psychology, 21, 1-11. (online), (http://wilkesed 520. Wikispaces.com/file/view/KWL+Article.pdf., accesed on 2015/04/1)

Carr, E. \& Ogle, D. 1987. KWL Plus: A strategy comprehension and summarization. Journal of Reading, 30, 626-631.

Chard, D. 2008. What is Reading Comprehension and Why it is important?. (Online at http;//myread.org/guide_stages.htm. accessed date 2015/03/26)

Corner, J. 2006. Instruction Reading Strategy: KWL (Know, Want to Know, Learned). (Online) (http://www.indiana.edu/ 1517/ KWL.htm. accessed date $2015 / 04 / 2$ )

Davey, B. 1983. Think Aloud: Modeling the Cognitive Processes of Reading Comprehension. Journal of Reading 27, no. 1 44-47.

Effendi, K.M. 2012. The Effectiveness of Using KWL Strategy to Increase Students' Reading Comprehension Achievement. Thesis. Malang: Islamic University of Malang Graduate Program English Education Department 
Eryawati, M. 2010. The Effectiveness of Three Phase Technique In Teaching Reading Comprehension Viewed From Intelligence. Thesis, (online), (http://www.perpus.univeristas .sebelasmaret.surakarta.pdf/accessed date 2015/03/20)

Finnochiaro \& Bonomo. 1973. The Foreign Language Learner: A guide for Teachers. New York: Regent Publishing Company, Inc

Fengjuan, Z. 2010. The Integration of the Know-Want-Learn (KWL) Strategy into English Language Teaching for Non-English Majors1. Chinese Journal of Applied Linguistics (Bimonthly) Vol. 33 No. 4. (online) accesed on April 1, 2015 from http://www.celea.org.cn/teic/92/10120605.p df.

Goodman, K. 1971. Reading:A psycholinguistic quessing game. Journal of the Reading Specialist. 4, 126-135.

Grellet, F. 1987. Developing Reading Skills, Great Britain: Cambridge University Press

Grellet, F. 1990. Developing Skill: A Practical Guide to Reading Comprehension Exercises. Cambridge University Press.

Harris, A.J. \& Sipay, E.R.1980. How to Increase Reading ability. New York: Longman Inc.

Latief, M.A. 2013. Research Methods on Language Learning: An Introduction. Malang: State University of Malang Press.

Mistar, J. 2010. Pedoman Penulisan Thesis. Malang: Program Pasca Sarjana UNISMA

Olson, J.P \& Diller, M.H. 1982. Learning to Teach Reading in Elementary School. London. MacMillan Publishing Company.

Ogle, D. 1986. K-W-L: A teaching model that develops active reading of expository text. Journal of Reading Teacher, 39, 564-570.

Petty, T. \& Jensen, M. 1987. Developing Children's Language. New York: Massachusetts, Allyn and Bacon Inc.

Region XIV Comprehensive Center Educational Testing Service. 1995. Learning Strategies Resource Guide. Georgia: educational testing service.

Riswanto. 2014. The Effect of Using KWL (Know, Want, Learned) Strategy on EFL Students' Reading Comprehension Achievement. International Journal of Humanities and Social Science, 14(1):23-51 
Ruddell . (Eds). Theoretical models and Processes of Reading. Newark, N.J.: International reading Association.

Santa, C. M. 1996. Project CRISS . Dubuque, Iowa: Kendall/Hunt

Stauffer, R. G. 1989. Developing Reading Maturity As a Cognitive Process. New York: Harper \& Row.

Sulistiani. 2012. The Effectiveness of KWL (Know/Want To Know/Learned) Strategy In Teaching Reading Comprehension To The Eight Grade Of MTSN Tumpang Malang. Thesis. Malang: Islamic University of Malang Graduate Program English Education Department

Sulistyo, G.H. 2011. Reading For Meaning :Thories Teaching Strategies and Assessment. Faculty of letters State University Malang: Pustaka Kaiswaran

Toprak, E. L. 2009. Three Reading Phases and Their Applications in the Teaching of English as a Foreign Language in Reading Classes with Young Learners. Journal of Language and Linguistic Studies, 12(1): 23-34.

Urquhart, A.H. \& Weir, C.J.1998. Reading in a second language: process, product and practice. London and New York: Longman.

Yusuf, A. 2012. Improving Student's Reading Comprehension Mastery of Narratives by Using Kinetic Novels. Final Project. Semarang: English Department FBS Unnes. 